\title{
A review of characterisation requirements for in-line prefermenters Paper 1: Wastewater characterisation
}

\author{
WH Rössle* and WA Pretorius \\ ERWAT Chair in Wastewater Management, Water Utilisation Division, Department of Chemical Engineering, University of Pretoria, \\ Pretoria 0001, South Africa
}

\begin{abstract}
The impact of wastewater prefermentation cannot be evaluated in isolation, based only on the local prefermenter biodegradable organic matter production rate, as represented by the volatile fatty acids concentration increase across the prefermenter. The nutrients ratio changes and solids removal variations from the raw to the settled sewage must be taken into account when considering the suitability of the prefermented wastewater for downstream biological nutrient removal processes. The raw and settled wastewater must, therefore, be characterised according to component nutrients and solids fractions. This paper reviews related wastewater characteristics required for in-line prefermenters, to establish simple strategies on which in-line prefermenter evaluations could be based.
\end{abstract}

\section{Nomenclature}

\begin{tabular}{|c|c|}
\hline APT & $=$ activated primary tank \\
\hline BCOD & $=$ biodegradable chemical oxygen demand \\
\hline BEPR & $=$ biological excess phosphorus removal \\
\hline BNRAS & $=$ biological nutrient removal activated sludge \\
\hline $\mathrm{C}$ & $=$ carbon \\
\hline COD & $=$ chemical oxygen demand \\
\hline F-RBCOD & $\begin{aligned}= & \text { fermentable readily biodegradable chemical } \\
& \text { oxygen demand }\end{aligned}$ \\
\hline GC & $=$ gas chromatography \\
\hline HAB & $=$ heterotrophic active biomass \\
\hline $\mathrm{N}$ & $=$ nitrogen \\
\hline N/A & $=$ not available \\
\hline $\mathrm{NH}_{3}$ & $=$ ammonia \\
\hline $\mathrm{NH}_{4}$ & $=$ ammonium \\
\hline $\mathrm{NH}_{3}+\mathrm{NH}_{4}-\mathrm{N}$ & $=$ total ammonia nitrogen \\
\hline $\mathrm{NO}_{3}$ & $=$ nitrate \\
\hline $\mathrm{NO}_{2}$ & $=$ nitrite \\
\hline$O-\mathrm{PO}_{4}$ & $=$ orthophosphate \\
\hline $\mathrm{P}$ & $=$ phosphorus \\
\hline PCOD & $=$ particulate chemical oxygen demand \\
\hline PST & $=$ primary settling tank \\
\hline RBCOD & $=$ readily biodegradable chemical oxygen demand \\
\hline SBCOD & $=$ slowly biodegradable chemical oxygen demand \\
\hline SCOD & $=$ soluble chemical oxygen demand \\
\hline SCVFA & $=$ short-chain volatile fatty acid \\
\hline SetS & $=$ settleable solids \\
\hline SS & suspended solids \\
\hline TDS & $=$ total dissolved solids \\
\hline TKN & $=$ total Kjeldahl nitrogen \\
\hline $\mathrm{TN}$ & $=$ total nitrogen \\
\hline TP & $=$ total phosphorus \\
\hline TS & $=$ total solids \\
\hline & $=$ unbiodegradable chemical ox \\
\hline
\end{tabular}

\footnotetext{
* To whom all correspondence should be addressed. 푱(011) 316-1304; fax (011) 316-1928; e-mail: wernerr@erwat.co.za Received 23 Aug 2000; accepted in revised form 4 April 2001.
}

$\begin{array}{lll}\text { UPCOD } & \text { unbiodegradable particulate chemical oxygen } \\ & \text { demand } \\ \text { USCOD } & \text { unbiodegradable soluble chemical oxygen } \\ & \text { demand } \\ \text { VFA } & \text { volatile fatty acid } \\ \text { VFA-COD } & =\text { equivalent COD for VFA } \\ \text { WCW } & =\text { water care works }\end{array}$

\section{Introduction}

The presence of appropriate proportions of the macro-nutrients $\mathrm{C}$, $\mathrm{N}$ and $\mathrm{P}$ in municipal wastewater is important for the efficient performance of a BNRAS process employing BEPR. These constituents are characterised by the TKN and the TP to COD ratios respectively. The TKN/COD ratio principally determines which BNRAS process configuration is the most appropriate, with a process feed ratio smaller than 0.07 to $0.08 \mathrm{mg} \mathrm{N} / \mathrm{mg}$ COD required for the frequently utilised 3-stage Phoredox process (Ekama et al., 1983). In a typical South African wastewater, the TKN/COD ratio range of 0.07 to 0.10 in the raw sewage changes towards 0.09 to $0.12 \mathrm{mg} \mathrm{N} / \mathrm{mg}$ COD in the settled sewage. Concurrently, the TP/ COD ratio range changes from 0.015 to 0.025 towards 0.02 to 0.03 $\mathrm{mg} \mathrm{P} / \mathrm{mg}$ COD (WRC, 1984). These ratio increases are due to the average 15 to $20 \% \mathrm{TKN}$ and TP removals against the higher average $40 \%$ COD removal occurring in the primary settling process. Solids removal taking place simultaneously can result in SetS and SS removal of about $90 \%$ and $60 \%$ respectively.

The change towards a low-strength settled sewage (low COD concentration) BNRAS reactor feed, lacking sufficient available biodegradable matter, can be counteracted by changing the settled sewage composition to contain more soluble organic matter. This can be accomplished by the prefermentation of the settled solids in the primary treatment process, where anaerobic bacteria hydrolyse biodegradable solids in the sludge to soluble organic compounds. These compounds can then be elutriated (washed) from the sludge and transferred to the settled sewage, where they are available as suitable carbon and energy sources in the downstream BNRAS process.

The full-scale implementation of prefermentation occurred only in the past 10 to 20 years at several WCW worldwide 


\begin{tabular}{|l|l|}
\hline \multicolumn{2}{|c|}{ Wastewater characterisation parameters for prefermenters } \\
\hline Parameter & Typical components \\
\hline Hydraulic & Flow rates and patterns, structural dimensions and tank configurations \\
\hline Composition & $\begin{array}{l}\text { Physical: solids, temperature, odour, colour } \\
\text { Organic: carbon, volatile acids } \\
\text { Inorganic non-metallic: nitrogen, phosphorus, pH }\end{array}$ \\
\hline Fractionation & Soluble, particulate, readily- and slowly biodegradable, and inert fractions \\
\hline Kinetic and stoichiometric & Growth, decay and hydrolysis rates, yields and half saturation coefficients \\
\hline
\end{tabular}

\begin{tabular}{|c|c|}
\hline \multicolumn{2}{|c|}{$\begin{array}{c}\text { TABLE } 2 \\
\text { Physical characterisation of wastewater solids for prefermenters }\end{array}$} \\
\hline Parameter & Characteristics of particles \\
\hline Floatable matter & $\begin{array}{l}\text { Fat, oil and grease, which form a scum layer on surfaces, and foreign floatable matter; } \\
\text { - visible with the naked eye, physically removable. }\end{array}$ \\
\hline Coarse suspended matter & $\begin{array}{l}\text { Particles readily settleable of colloidal and non-colloidal nature (particle size }>1 \mu \mathrm{m} \text { ); } \\
-\quad \text { microscopically visible, filterable. }\end{array}$ \\
\hline Colloidal dispersed matter & $\begin{array}{l}\text { Fine particles not readily settleable (particle size } 1 \mu \mathrm{m} \text { to } 1 \mathrm{~nm} \text { ); } \\
\text { - ultra-microscopically visible, non-filterable, chemically flocculable. }\end{array}$ \\
\hline Molecular solution matter & $\begin{array}{l}\text { Constituents in true solution (dissolved) (particle size }<1 \mathrm{~nm} \text { ); } \\
\text { - not visible by any instrumental method, not removable with conventional WCW } \\
\text { treatment processes. }\end{array}$ \\
\hline
\end{tabular}

(Gonçalves et al., 1994; Münch, 1998). Consequently, the performance of prefermenters often remains unmonitored and uncontrolled, mostly due to the lack of analytical facilities. Randall et al. (1992) observed that prefermenter process monitoring is mostly done on a "may-it-hit" basis. Little attention is usually paid to the prefermenter performance if sufficient nutrient removal is achieved in the downstream BNRAS process (Münch and Koch, 1998). Research is directed on quantifying the $\mathrm{C}, \mathrm{N}$ and $\mathrm{P}$ fractions in the secondary treatment processes (BNRAS reactor), without due emphasis placed on the changes occurring in the primary treatment process.

The purpose of this review paper is to identify typical wastewater characteristic changes reported in the literature for primary settled and prefermented wastewater, applicable for a basic in-line APT and other prefermenter configurations. The determination of the variable characteristics of the raw wastewater and the constituent changes in the prefermenter form a starting point for prefermentation and BNRAS process evaluations.

\section{Wastewater characterisation}

The input data required for process and wastewater characterisation have been presented (Urbain et al., 1998) as hydraulic, composition, fractionation and kinetic parameters, as listed in Table 1. The hydraulic and composition parameters form the basis of an in-line prefermenter evaluation. The hydraulic parameter includes the volumetric inflow and diurnal flow patterns, sludge wastage and sludge recycle flow rates, obtained fromflow meters or approximated from pump deliveries. The physical structural details required include features such as tank and stilling chamber volumes, vertical wall height, available surface (centre-feed stilling chamber surface excluded), and conical settling zone volume. The composition parameters include solids and nutrient $(\mathrm{C}, \mathrm{N}$ and $\mathrm{P})$ concentrations in the liquid and sludge streams, preferably obtained from representative composite samples, and from these samples the various biodegradable and unbiodegradable fractions can be obtained. Kinetic parameters are excluded in this review for a basic prefermenter evaluation.

\section{Solids material}

The physical characterisation of WCW influent is developed according to the relative size and condition of solids particles. Murray (1991) characterised the PST feed into four categories, based on the settling properties of the constituent material. This classification can be combined with the characterisation of a dispersed system (a two-phase system with dispersed particles in a liquid dispersion medium), as applicable to untreated wastewater (WRC, 1984). The physical characterisation of the APT feed (screened and degritted) is summarised in Table 2.

The constituents in solution move largely unchanged through the prefermentation process (Tchobanoglous and Burton, 1991). 
TABLE 3

Classification of wastewater solids as constituent percentages

\begin{tabular}{|c|c|c|c|c|c|c|c|}
\hline \multicolumn{8}{|c|}{ TS: $100 \%$} \\
\hline \multicolumn{4}{|c|}{ Non-filterable or SS: $30 \%$} & \multicolumn{4}{|c|}{ Filterable: $70 \%$} \\
\hline \multicolumn{2}{|c|}{ SetS: $22 \%$} & \multicolumn{2}{|c|}{ Non-settleable: $8 \%$} & \multicolumn{2}{|c|}{ TDS: $63 \%$} & \multicolumn{2}{|c|}{ Colloidal: $7 \%$} \\
\hline Volatile: $17 \%$ & Fixed: $5 \%$ & Volatile: $6 \%$ & Fixed: $2 \%$ & Volatile: $22 \%$ & Fixed: $41 \%$ & Volatile: $6 \%$ & Fixed: $1 \%$ \\
\hline
\end{tabular}

TABLE 4

Classification of raw and settled wastewater total COD as constituent fractions of total COD

\begin{tabular}{|c|c|c|c|c|c|}
\hline \multicolumn{6}{|c|}{$\begin{array}{l}\text { COD (Raw and settled): } 1.0 \\
\text { SCOD: } 0.30 \text {; PCOD: } 0.70\end{array}$} \\
\hline \multicolumn{3}{|c|}{$\begin{array}{c}\text { BCOD } \\
\text { Raw: } 0.75 \text { to } 0.85 \\
\text { Settled: } 0.80 \text { to } 0.95\end{array}$} & \multicolumn{2}{|c|}{$\begin{array}{c}\text { UCOD } \\
\text { Raw: } 0.15 \text { to } 0.25 \\
\text { Settled: } 0.05 \text { to } 0.20\end{array}$} & \multirow[t]{3}{*}{$\begin{array}{c}\text { HAB } \\
\text { Raw: } 0 \\
\text { Settled: } 0\end{array}$} \\
\hline \multicolumn{2}{|c|}{$\begin{array}{c}\text { RBCOD } \\
\text { Raw: } 0.08 \text { to } 0.25 \\
\text { Settled: } 0.10 \text { to } 0.35\end{array}$} & \multirow[t]{2}{*}{$\begin{array}{c}\text { SBCOD } \\
\text { Raw: } 0.50 \text { to } 0.77 \\
\text { Settled: } 0.45 \text { to } 0.85\end{array}$} & \multirow[t]{2}{*}{$\begin{array}{c}\text { USCOD } \\
\text { Raw: } 0.04 \text { to } 0.10 \\
\text { Settled: } 0.05 \text { to } 0.20\end{array}$} & \multirow[t]{2}{*}{$\begin{array}{c}\text { UPCOD } \\
\text { Raw: } 0.07 \text { to } 0.20 \\
\text { Settled: } 0.00 \text { to } 0.10\end{array}$} & \\
\hline $\begin{array}{c}\text { SCVFA } \\
\text { Raw: } 0.008 \text { to } 0.10 \\
\text { Settled: } 0.01 \text { to } 0.14\end{array}$ & $\begin{array}{c}\text { F-RBCOD } \\
\text { Raw: } 0.048 \text { to } 0.225 \\
\text { Settled: } 0.06 \text { to } 0.315\end{array}$ & & & & \\
\hline
\end{tabular}

The suspended matter of colloidal nature, which does not settle easily, is the main solids fraction in the APT settled sewage overflow (supernatant) that must be treated in the downstream BNRAS processes (Murray, 1991). The excessive carry-over of coarse SS from the APT occurs in practice, usually due to solids overloading, inappropriate operational procedures, or design inadequacies.

The TS material can be characterised according to a nonfilterable (or SS) and a filterable solids fraction. The non-filterable fraction consists of a settleable and a non-settleable fraction, and the filterable fraction consists of a total dissolved solids (TDS) and a colloidal fraction. Each of these four fractions consists of a volatile (organic) and a fixed (inert) fraction. Typical reference data for the solids fractions, calculated as percentages of the TS, are presented in Table 3 (adapted from WRC, 1984; Tchobanoglous and Burton, 1991). The evaluation of the SS and the SetS in the liquid streams and the TS in the settled sludge are used to determine solids removal across an in-line APT.

\section{Carbonaceous material}

The carbonaceous material content of the wastewater is estimated by the COD (WRC, 1984). The typical COD chemical subdivision into three main fractions, biodegradable (organic) COD (BCOD), unbiodegradable (inert) COD (UCOD) and heterotrophic active biomass (HAB), has been reported in detail (Mbewe et al., 1995). The HAB fraction is approximated as zero in a typical South African prefermenter feed, as the influent is considered to be anaerobic, not seeded with recirculated-activated sludge, and the wastewater is not supporting active biomass generation. The UCOD is further subdivided into particulate (UPCOD) and soluble
(USCOD) COD fractions, based on physical settling properties. The BCOD is further subdivided into slowly (SBCOD) and readily biodegradable (RBCOD) COD fractions, based on biokinetic responses. The RBCOD can be further subdivided into short-chain volatile fatty acids (SCVFA) and non-SCVFA. These two divisions are normally represented by VFA and fermentable (non-SCVFA) RBCOD (F-RBCOD). An alternative COD subdivision, into two physical fractions, contains a total soluble (SCOD) and a total particulate (PCOD) COD component. Typical reference data for South African domestic wastewater COD fractions, based on total COD, are presented in Table 4 (adapted from WRC, 1984; Dold et al., 1991; Mbewe et al., 1995; Xu and Hultman, 1996; Park et al., 1997; Wilson et al., 1998).

The UCOD fractions presented in Table 4 behave as conservative substances, playing a negligible role in the prefermentation process (Randall et al., 1992). The particulate material (UPCOD) is mainly removed with the waste sludge and the soluble material (USCOD) passes through the prefermentation processes largely unchanged. The BCOD fractions presented in Table 4 are used by organisms in the BNRAS process (Lilley et al., 1997), with the soluble material (RBCOD) being used more rapidly than the slowly biodegradable (SBCOD) material, as measured by oxygen or nitrate utilisation rate tests (Naidoo et al., 1998; Urbain et al., 1998). The SCVFA fraction is increased in a prefermenter with the solubilisation of SBCOD to RBCOD, and the fermentation of F-RBCOD to SCVFA. The component fractions are listed in Table 4 to indicate the general relationship between COD and SCVFA, and a schematic presentation in Appendix A (Fig. 1) illustrates the component percentage fractions of the total COD. 
TABLE 5

Short-chain volatile fatty acids characteristics and COD equivalents

\begin{tabular}{|l|c|c|c|c|}
\hline Common name & \multicolumn{2}{|c|}{ Formulae } & $\begin{array}{c}\text { Molecular } \\
\text { mass } \\
\text { [g/mol] }\end{array}$ & $\begin{array}{c}\text { COD Equi- } \\
\text { valent } \\
\text { [g COD } \\
\text { /g acid] }\end{array}$ \\
\hline \multicolumn{2}{|c|}{} & & & \\
formic acid & $\mathrm{HCOOH}$ & $\mathrm{CO}_{2} \mathrm{H}_{2}$ & 46.00 & 0.348 \\
acetic acid & $\mathrm{CH}_{3} \mathrm{COOH}$ & $\mathrm{C}_{2} \mathrm{O}_{2} \mathrm{H}_{4}$ & 60.05 & 1.067 \\
propionic acid & $\mathrm{CH}_{3} \mathrm{CH}_{2} \mathrm{COOH}$ & $\mathrm{C}_{3} \mathrm{O}_{2} \mathrm{H}_{6}$ & 74.08 & 1.514 \\
n-butyric acid or iso-butyric acid & $\mathrm{CH}_{3}\left(\mathrm{CH}_{2}\right)_{2} \mathrm{COOH}$ & $\mathrm{C}_{4} \mathrm{O}_{2} \mathrm{H}_{8}$ & 88.11 & 1.818 \\
n-valeric acid or iso-valeric acid & $\mathrm{CH}_{3}\left(\mathrm{CH}_{2}\right)_{3} \mathrm{COOH}$ & $\mathrm{C}_{5} \mathrm{O}_{2} \mathrm{H}_{10}$ & 102.13 & 2.039 \\
n-caproic acid or iso-caproic acid & $\mathrm{CH}_{3}\left(\mathrm{CH}_{2}\right)_{4} \mathrm{COOH}$ & $\mathrm{C}_{6} \mathrm{O}_{2} \mathrm{H}_{12}$ & 116.16 & 2.207 \\
\hline
\end{tabular}

\section{TABLE 6}

Typical VFA composition distributions for prefermenters, with VFA-COD equivalents

\begin{tabular}{|c|c|c|c|c|c|c|l|}
\hline $\begin{array}{c}\text { Acetic } \\
\text { acid } \\
\text { weight } \\
\text { [\%] }\end{array}$ & $\begin{array}{c}\text { Propionic } \\
\text { acid } \\
\text { weight } \\
\text { [\%] }\end{array}$ & $\begin{array}{c}\text { Butyric } \\
\text { acid } \\
\text { weight } \\
\text { [\%] }\end{array}$ & $\begin{array}{c}\text { Valeric } \\
\text { acid } \\
\text { weight } \\
\text { [\%] }\end{array}$ & $\begin{array}{c}\text { Other } \\
\text { acid } \\
\text { weight } \\
\text { [\%] }\end{array}$ & $\begin{array}{c}\text { Total } \\
\text { acid } \\
\text { weight } \\
\text { [\%] }\end{array}$ & $\begin{array}{c}\text { VFA-COD } \\
\text { g COD } \\
\text { /g VFA } \\
\text { (calcula- } \\
\text { ted to } \\
\mathbf{1 0 0 \% )} \\
\text { [g/g] }\end{array}$ & Reference \\
\hline 38 & 36 & 16 & 10 & - & 90 & 1.38 & Pitman et al., 1992 \\
43 & 41 & 8 & - & - & 92 & 1.33 & Randall et al., 1992 \\
70 & 25 & 5 & - & - & 100 & 1.22 & Carlsson et al., 1996 \\
56 & 30 & 7 & 0 & 7 & 93 & 1.27 & Rabinowitz et al., 1997 \\
71 & 24 & 3 & 3 & - & 101 & 1.22 & Münch, 1998 \\
61 & 27 & 7 & - & - & 95 & 1.25 & Münch, 1998 \\
55 & 45 & 0 & 0 & - & 100 & 1.27 & Münch, 1998 \\
Münch, 1998 \\
49
\end{tabular}

\begin{tabular}{|c|c|c|c|c|c|}
\hline \multicolumn{6}{|c|}{$\begin{array}{c}\text { TABLE } 7 \\
\text { Classification of raw and settled wastewater total nitrogen as constituent fractions of total nitrogen }\end{array}$} \\
\hline \multicolumn{6}{|c|}{ TN: 1.0} \\
\hline \multicolumn{5}{|c|}{ TKN: 0.99 to 1.0} & \multirow{4}{*}{$\begin{array}{c}\mathrm{NO}_{3} \& \mathrm{NO}_{2} \\
\text { Raw: } 0 \text { to } 0.01 \\
\text { Settled: } 0 \text { to } 0.01\end{array}$} \\
\hline \multicolumn{4}{|c|}{$\begin{array}{l}\text { Organically bound } \mathrm{N} \\
\text { Raw: } 0.25 \text {; Settled: } 0.17\end{array}$} & \multirow{3}{*}{$\begin{array}{c}\text { Inorganic } \mathrm{NH}_{3} \& \mathrm{NH}_{4} \\
\text { Raw: } 0.75 \\
\text { Settled: } 0.83 \\
\text { Raw: } 0.50 \text { to } 0.75 \text { (USA) } \\
\text { Settled: } 0.60 \text { to } 0.85 \text { (USA) }\end{array}$} & \\
\hline \multicolumn{2}{|c|}{$\begin{array}{l}\text { Biodegradable } \\
\text { Raw: } 0.12 ; \text { Settled: } 0.13\end{array}$} & \multicolumn{2}{|c|}{$\begin{array}{l}\text { Unbiodegradable } \\
\text { Raw: 0.13; Settled: } 0.04\end{array}$} & & \\
\hline $\begin{array}{c}\text { Particulate } \\
\text { Raw: } 0.06 \\
\text { Settled: } 0.065\end{array}$ & $\begin{array}{c}\text { Soluble } \\
\text { Raw: } 0.06 \\
\text { Settled: } 0.065\end{array}$ & $\begin{array}{l}\text { Particulate } \\
\text { Raw: } 0.10 \\
\text { Settled: } 0.0\end{array}$ & $\begin{array}{c}\text { Soluble } \\
\text { Raw: } 0.03 \\
\text { Settled: } 0.04\end{array}$ & & \\
\hline
\end{tabular}




\begin{tabular}{|c|c|c|}
\hline \multicolumn{3}{|c|}{$\begin{array}{c}\text { TABLE } 8 \\
\text { Classification of wastewater phosphorus as constituent } \\
\text { percentages of total phosphorus }\end{array}$} \\
\hline \multicolumn{3}{|c|}{ TP: $100 \%$} \\
\hline $\begin{array}{l}\text { orthophosphate } \\
\text { Raw \& settled: } 70 \text { to } 90 \% \\
\text { Raw (USA): } 42 \text { to } 57 \%\end{array}$ & $\begin{array}{c}\text { polyphosphate } \\
\text { Raw (USA): } 29 \text { to } 33 \%\end{array}$ & $\begin{array}{c}\text { Organic phosphate } \\
\text { Raw (USA): } 14 \text { to } 25 \%\end{array}$ \\
\hline
\end{tabular}

\section{Volatile fatty acids}

The fatty acids, forming part of the RBCOD group, are the key products require from the prefermentation process. Fatty acids are organic acids, consisting of a number of carbon atoms arranged in a straight chain. An alkyl group $\left(\mathrm{CH}_{3}-\right)$ at one end of a straight or branched carbon chain and a carboxyl group $(-\mathrm{COOH})$ at the other end, combine to form carboxylic acids in the structure $\mathrm{CH}_{3}-\left(\mathrm{CH}_{2}\right)_{\mathrm{i}}$ COOH (Murray, 1991; Münch, 1998), with $i$ representing the number of carbon atoms.

The water soluble SCVFAs are an ideal substrate for the BNRAS process, and specifically the BEPR process (Osborn et al., 1986). Münch (1998) refers to $i$ as smaller or equal to six for SCVFA, as listed in Table 5. The one carbon SCVFA (formic acid) does not support BEPR (Randall et al., 1997) and the six carbon SCVFA (caproic acid) is present in negligible quantities. The terms VFA and SCVFA are often considered to be synonymous in the wastewater field (Buchauer, 1998).

Several researchers, as listed in Table 6, have reported VFA compositions detected at individual WCW. Acetic acid is predominant, followed by propionic, butyric and valeric acid, with acetic acid also being the preferred substrate for BEPR (Skalsky and Daigger, 1995; Randall et al., 1997). The linear forms of SCVFA are preferentially consumed before the branched forms (Moser-Engeler et al., 1998).

The typical VFA compositions reported in prefermenter effluents, as listed in Table 6 , can be used to calculate an approximation of the equivalent COD for VFA (VFA-COD). This generalisation is necessary at WCW where gas chromatography (GC) analyses are not available (Rössle, 1999). The GC analyses are ideally required to identify individual VFA, and simple titration procedures will only supply an approximation of the total VFA concentration (De Haas and Adam, 1995; Buchauer, 1998). In fullscale prefermenters with primary sludge feed (a side-stream configuration), the reported VFA-COD equivalent is between 1.24 to $1.40 \mathrm{~g} \mathrm{COD} / \mathrm{g}$ VFA (Münch, 1998).

\section{Nitrogenous material}

The nitrogenous compounds, termed TN, are in the form of organic (proteinaceous) nitrogen and inorganic total ammonia nitrogen $\left(\mathrm{NH}_{3}+\mathrm{NH}_{4}-\mathrm{N}\right)$, represented together by the TKN, and oxidised nitrogen compounds, such as nitrate $\left(\mathrm{NO}_{3}-\mathrm{N}\right)$ and nitrite $\left(\mathrm{NO}_{2}-\mathrm{N}\right)$ nitrogen. The oxidised nitrogen compounds are usually present in low quantities in typical South African anaerobic raw and settled sewage. The inorganic total ammonia nitrogen exists in solution as ammonia $\left(\mathrm{NH}_{3}-\mathrm{N}\right)$ and ammonium nitrogen $\left(\mathrm{NH}_{4}-\mathrm{N}\right)$. These fractions depend on the $\mathrm{pH}$, with $\mathrm{NH}_{4}-\mathrm{N}$ being predominant at conditions with a pH below 7 (Tchobanoglous and Burton, 1991), as found in the prefermenter sludge.
It is difficult to fractionate organically bound nitrogen (e.g. protein, urea) into biodegradable and unbiodegradable soluble and particulate fractions, and such a subdivision is not required for a basic prefermentation evaluation (Park et al., 1997). Bacterial decomposition and hydrolysis convert organically bound nitrogen to ammonia and ammonium nitrogen. Typical reference data for the nitrogenous fractions in South African (unless stated) domestic wastewater are presented in Table 7 (adapted from WRC, 1984; Dold et al., 1991; Park et al., 1997; Wilson and Dold, 1998).

The unbiodegradable particulate and soluble nitrogen fractions presented in Table 7 are handled in a similar fashion as the conservative UCOD. The evaluation of the TKN and the $\mathrm{NH}_{3}+\mathrm{NH}_{4}-$ $\mathrm{N}$ fractions of liquid and sludge streams at an APT are used to determine the changes in TKN/COD nutrient ratio and the concurrent ammonia fraction changes across the prefermenter. The component fractions are listed in Table 7 to indicate the general relationship between $\mathrm{TN}$ and nitrogen fractions and a schematic presentation in Appendix A (Fig. 2) illustrates the percentage fractions of TN.

\section{Phosphorus material}

The phosphorus compounds, predominantly found in wastewater as phosphates, can be categorised by physical means (dissolved and particulate fractions) and by chemical means as phosphate compounds (Park et al., 1997). The chemical fractions consist of dissolved inorganic orthophosphate $\left(o-\mathrm{PO}_{4}\right)$, polyphosphate or condensed phosphate, and organically bound phosphate (Tchobanoglous and Burton, 1991). The orthophosphates $\left(\mathrm{PO}_{4}^{-3}\right.$, $\mathrm{HPO}_{4}^{-2}, \mathrm{H}_{2} \mathrm{PO}_{4}^{-}$, and $\mathrm{H}_{3} \mathrm{PO}_{4}$ ), usually the predominant fraction in South African wastewater, are available for biological metabolism without further breakdown. The polyphosphates include two or more $\mathrm{P}$ atoms (e.g. $\mathrm{P}_{3} \mathrm{O}_{10}{ }^{-5}, \mathrm{P}_{2} \mathrm{O}_{7}^{-2}$ ) in a complex molecule, and revert together with the organic phosphates through a slow-rate hydrolysis process to the soluble $o-\mathrm{PO}_{4}$ form. The organic phosphorus fraction refers to phosphate in organic chemicals such as cells, pesticides and detergents, for which typical soluble and particulate constituent percentages are not available. Typical reference data for the phosphorus fractions in South African (unless stated) domestic wastewater are presented in Table 8 (adapted from WRC, 1984; Tchobanoglous and Burton, 1991; Park et al., 1997).

An APT evaluation is based on the TP and $o-\mathrm{PO}_{4}$ fractions of liquid and sludge streams to determine the changes in the TP/COD ratio and the concurrent $o-\mathrm{PO}_{4}$ fraction change across the prefermenter.

\section{Wastewater nutrient ratios}

The day-to-day wastewater constituent concentrations usually exhibit considerable variations, but the ratios of constituents 


\begin{tabular}{|c|c|c|c|c|c|c|}
\hline \multicolumn{7}{|c|}{$\begin{array}{c}\text { TABLE 9 } \\
\text { Characteristic ratios for raw and settled municipal wastewater }\end{array}$} \\
\hline Ratio & Units & $\begin{array}{c}\text { Raw } \\
\text { sewage }\end{array}$ & $\begin{array}{l}\text { Settled } \\
\text { sewage }\end{array}$ & Country & $\begin{array}{l}\text { Fermenter } \\
\text { included }\end{array}$ & Reference \\
\hline TKN/COD & $\mathrm{mg} \mathrm{N} / \mathrm{mg}$ COD & $\begin{array}{l}0.07 \text { to } 0.10 \\
\text { N/A } \\
0.06\end{array}$ & $\begin{array}{l}0.09 \text { to } 0.12 \\
0.10 \text { to } 0.125 \\
0.08\end{array}$ & $\begin{array}{l}\text { RSA } \\
\text { USA } \\
\text { RSA }\end{array}$ & $\begin{array}{l}\text { NO } \\
\text { NO } \\
\text { YES }\end{array}$ & $\begin{array}{l}\text { WRC, 1984; Ekama et al., } 1983 \\
\text { Randall et al., } 1992 \\
\text { Rössle, } 1999\end{array}$ \\
\hline TP/COD & $\mathrm{mg} \mathrm{P} / \mathrm{mg}$ COD & $\begin{array}{l}0.015 \text { to } 0.025 \\
\quad 0.028\end{array}$ & $\begin{array}{l}0.020 \text { to } 0.030 \\
0.04\end{array}$ & $\begin{array}{l}\text { RSA } \\
\text { USA }\end{array}$ & $\begin{array}{l}\text { NO } \\
\text { NO }\end{array}$ & $\begin{array}{l}\text { WRC, 1984; Ekama et al., } 1983 \\
\text { Randall et al., } 1992\end{array}$ \\
\hline$\left(\mathrm{NH}_{3}+\mathrm{NH}_{4}-\mathrm{N}\right) / \mathrm{TKN}$ & $\mathrm{mg} \mathrm{N} / \mathrm{mg} \mathrm{N}$ & $\begin{array}{l}0.6 \text { to } 0.8 \\
0.83\end{array}$ & $\begin{array}{l}0.7 \text { to } 0.9 \\
\text { N/A }\end{array}$ & $\begin{array}{c}\text { RSA } \\
\text { Australia }\end{array}$ & $\begin{array}{l}\text { NO } \\
\text { NO }\end{array}$ & $\begin{array}{l}\text { WRC, } 1984 \\
\text { Münch, } 1998\end{array}$ \\
\hline $\begin{array}{l}O-\mathrm{PO}_{4} / \mathrm{TP} \\
\text { SetS/SS } \\
\text { SCOD/COD } \\
\text { VFA/SCOD } \\
\text { VFA/COD } \\
\text { SCVFA/F-RBCOD }\end{array}$ & $\begin{array}{c}\mathrm{mg} \mathrm{P} / \mathrm{mg} \mathrm{P} \\
\mathrm{ml} \mathrm{SetS} / \mathrm{mg} \mathrm{SS} \\
\mathrm{mg} \mathrm{COD} / \mathrm{mg} \mathrm{COD} \\
\mathrm{mg} \mathrm{COD} / \mathrm{mg} \mathrm{COD} \\
\mathrm{mg} \mathrm{COD} / \mathrm{mg} \mathrm{COD} \\
\mathrm{mg} \mathrm{COD} / \mathrm{mg} \mathrm{COD}\end{array}$ & $\begin{array}{c}0.7 \text { to } 0.9 \\
0.02 \text { to } 0.03 \\
0.33 \\
0.60 \text { to } 0.75 \\
\text { N/A } \\
\text { N/A }\end{array}$ & $\begin{array}{c}0.7 \text { to } 0.9 \\
0 \text { to } 0.006 \\
\text { N/A } \\
0.60 \text { to } 0.75 \\
0.09 \\
1.0\end{array}$ & $\begin{array}{c}\text { RSA } \\
\text { RSA } \\
\text { Australia } \\
\text { Australia } \\
\text { RSA } \\
\text { RSA }\end{array}$ & $\begin{array}{l}\text { NO } \\
\text { NO } \\
\text { NO } \\
\text { YES } \\
\text { YES } \\
\text { YES }\end{array}$ & $\begin{array}{l}\text { WRC, } 1984 \\
\text { WRC, } 1984 \\
\text { Münch, } 1998 \\
\text { Münch, } 1998 \\
\text { Banister et al., } 1998 \\
\text { Wentzel et al., } 1991\end{array}$ \\
\hline
\end{tabular}

accommodate such fluctuations to some extent (Wilson and Dold, 1998). The constituent ratios can be used as fairly representative benchmarks to characterise the wastewater for BNRAS evaluations. Typical nutrient ratios and fractions for raw and settled sewage are summarised in Table 9.

Primary settling (and prefermentation) can have a detrimental effect on the desired wastewater characteristics for a downstream BNRAS process. The nutrient TKN/COD and TP/COD ratios increase due to a larger COD settling and removal rate compared to TKN and TP (Ekama et al., 1983), combined with the release of $\mathrm{N}$ and P due to hydrolysis. About $0.09 \mathrm{mg} \mathrm{N} \mathrm{NH}_{3}$ and about 0.035 $\mathrm{mg} / \ell \mathrm{P}$ of $o-\mathrm{PO}_{4}$ are solubilised for every $1.0 \mathrm{mg}$ SCVFA (as acetic acid) produced (Banister et al., 1998). This nutrient release has also been reported as 0.02 to $0.06 \mathrm{mg} \mathrm{NH}_{4}-\mathrm{N} / \mathrm{mg} \mathrm{COD}$ and a maximum of $0.005 \mathrm{mg} o-\mathrm{PO}_{4}-\mathrm{P} / \mathrm{mg}$ COD hydrolysed (Moser-Engeler et al., 1998). Wastewater with high nutrient ratios will not produce adequate denitrification for certain BNRAS process configurations, which is a prerequisite for BEPR (Siebritz et al., 1983; Pitman, 1991). The strength of the settled sewage must also be considered, together with the TKN/COD ratio, as the COD content in the settled sewage contributes to the establishment of anaerobic conditions in the anaerobic zone of the BNRAS reactor (Barnard, 1983).

Substantial COD consumption takes place during the BNRAS process (Randall et al., 1992). About $8.6 \mathrm{mg} / \ell \mathrm{COD}$ is needed to reduce $1 \mathrm{mg} / \ell \mathrm{NO}_{3}-\mathrm{N}$ to nitrogen gas during denitrification, and about $50 \mathrm{mg} / \ell \mathrm{COD}$, or 7 to $9 \mathrm{mg} / \ell$ VFA (Rodríguez et al., 1998), is required per $1 \mathrm{mg} / \ell \mathrm{TP}$ removed. The most efficient type of COD fraction utilised during denitrification and phosphate removal is VFA, which can be increased in the prefermentation process. A low strength BNRAS process feed (COD $<250 \mathrm{mg} / \ell$, Tchobanoglous and Burton, 1991) can therefore reduce the BNRAS performance. At a TP/COD ratio of greater than 0.02 simultaneous chemical phosphorus precipitation will be necessary (Pitman, 1991). When the TKN/COD ratio is higher than 0.11 and the VFA content is low (VFA $<50 \mathrm{mg} / \ell$ ), an external carbon source should be used (such as methanol, which can be costly), the anaerobic zone of BNRAS reactor must be enlarged (limited, due to civil structure size), or prefermentation must be implemented (Pitman, 1991; Randall et al., 1992). Prefermentation is currently incorporated as a standard practice worldwide at many WCW, even at BNRAS feed TKN/ COD ratios of lower than 0.11 .

\section{Conclusions}

The efficiency of sewage prefermentation cannot be evaluated in isolation, based only on the local prefermenter VFA production rate (or soluble organic matter transformations). This review has highlighted the importance of identifying the increased nutrient ratios in the settled sewage from a prefermenter. The higher ratios can contribute to downstream performance failures for certain BNRAS process configurations. The changes in the SCVFA concentration across the prefermenter must be supported at least with nutrients and solids characteristics, to ensure that a suitable BNRAS process feed is available.

\section{Acknowledgements}

The authors wish to thank ERWAT for assistance provided during the preparation of this paper.

\section{References}

BANISTER SS, PITMAN AR and PRETORIUS WA (1998) The solubilisation of $\mathrm{N}$ and $\mathrm{P}$ during primary sludge acid fermentation and precipitation of the resultant P. Water SA 24 (4) 337-342.

BARNARD JL (1983) Background to biological phosphorus removal. Water Sci. Technol. 15 (3/4) 1-13.

BUCHAUER K (1998) A comparison of two simple titration procedures to determine volatile fatty acids in influents to wastewater and sludge treatment processes. Water SA 24 (1) 49-56.

CARLSSON H, ASPEGREN H and HILMER A (1996) Interactions between wastewater quality and phosphorus release in the anaerobic reactor of the EBPR process. Water Res. 30 (6) 1517-1527.

DE HAAS DW and ADAM N (1995) Use of a simple titration procedure to determine $\mathrm{H}_{2} \mathrm{CO}_{3} *$ alkalinity and volatile acids for process control in wastewater treatment. Water SA 21 (4) 307-318.

DOLD PL, WENTZEL ML, BILLING AE and MARAIS GvR (1991) Activated Sludge System Simulation Programs: Nitrification and Nitrification / Denitrification Systems, Version 1. WRC Report No TT 52/91. 
EKAMA GA, SIEBRITZ IP and MARAIS GVR (1983) Considerations in the Process Design of Nutrient Removal Activated Sludge Processes. Water Sci. Technol. 15 283-318.

GONÇALVES RF, CHARLIER AC and SAMMUT F (1994) Primary fermentation of soluble and particulate organic matter for wastewater treatment. Water Sci. Technol. 30 (6) 53-62.

LILLEY ID, PYBUS PJ and POWER SPB (1997) Operating Manual for Biological Nutrient Removal Wastewater Treatment Works. WRC Report No TT 83/97.

MBEWE A, WENTZEL MC, LAKAY MT and EKAMA GA (1995) Characterisation of the Carbonaceous Materials in Municipal Wastewaters. Dept. Civil Eng. Report No W84, Univ. of Cape Town, Cape Town, South Africa.

MOSER-ENGELER R, UDERT KM, WILD D and SIEGRIST H (1998) Products from primary sludge fermentation and their suitability for nutrient removal. Water Sci. Technol. 38 (1) 265-273.

MÜNCH E and KOCH FA (1998) VFA Production in Australian and Canadian Prefermenters. Water 25 (1) 34-36.

MÜNCHE(1998) DSP-Prefermenter Technology Book. Science Traveller International, Advanced Wastewater Management Centre, Brisbane, Australia.

MURRAY KA (1991) Wastewater Treatment and Pollution Control (2 $2^{\text {nd }}$ edn.) WRC, South Africa.

NAIDOO V, URBAIN V and BUCKLEY CA (1998) Characterization of Wastewater and Activated Sludge from European Municipal Wastewater Treatment Plants using the NUR test. Water Sci. Technol. 38 (1) 303-310.

OSBORN D W, LÖTTER LH, PITMAN AR and NICHOLLS HA (1986) Report to the Water Research Commission on a Three Year Study on the Enhancement of Biological Phosphate Removal by Altering Process Feed Composition. WRC Report No 137/1/86.

PARK JK, WANG J and NOVOTNY G (1997) Wastewater Characterisation for Evaluation of Biological Phosphorus Removal: Wastewater Fractionation. WDNR Research Report 174, Wisconsin Dept. of Natural Resources, Wisconsin-Madison, USA. (www.dnr.state.wi.us).

PITMAN AR (1991) Design considerations for nutrient removal plants. Water Sci. Technol. 23 (4-6) 781-790.

PITMAN AR, LÖTTER LH, ALEXANDER WV and DEACON SL (1992) Fermentation of raw sludge and elutriation of resultant fatty acids to promote excess biological phosphorus removal. Water Sci. Technol. 25 (4-5) 185-194.

RABINOWITZ B, FRIES MK, DAWSON RN, KELLER W and DO P (1997) Biological nutrient removal at the Calgary Bonnybrook WWTP replaces costly chemical phosphorus removal. Proc. $70^{\text {th }}$ Ann. Conf. \& Expo. of the Water Environ. Fed. October 15-19, Chicago, USA, 643655 .
RANDALL CW, BARNARD JL and STENSEL HD (1992) Design and retrofit of wastewater treatment plants for biological nutrient removal. In: Eckenfelder WW, Malina JF and Patterson JW (Library eds.) ( $1^{\text {st }}$ edn.) Water Quality Management Library, Vol.5, Technomic Publishing Company, Lancaster, Pennsylvania, USA.

RANDALL AA, BENEFIELD LD and HILL WE (1997) Induction of phosphorus removal in an enhanced biological phosphorus removal bacterial population. Water Res. 31 (11) 2869-2877.

RODRÍGUEZ GC, GONZÁLEZ-BARCELÓ O and GONZÁLEZMARTÍNEZ S (1998) Wastewater fermentation and nutrient removal in sequencing batch reactors. Water Sci. Technol. 38 (1) 255-264.

RÖSSLE WH (1999) Liquid and Solids Management Impact on Nutrient Ratios for In-line Wastewater Prefermenters. M. Eng. Dissertation, Univ. of Pretoria, Pretoria, South Africa.

SIEBRITZ IP, EKAMA GA and MARAIS GvR (1983) A parametric model for biological excess phosphorus removal. Water Sci. Technol. 15 127-152.

SKALSKY DS and DAIGGER GT (1995) Wastewater solids fermentation for volatile acid production and enhanced biological phosphorus removal. Water Environ. Res. 67 (2) 230-237.

TCHOBANOGLOUS G and BURTONFL(1991) Wastewater Engineering: Treatment, Disposal and Reuse ( $3^{\text {rd }}$ edn.) Metcalf and Eddy Inc., McGraw-Hill, New York, USA.

URBAIN V, NAIDOO V, GINESTET P and BUCKLEY CA (1998) Characterisation of wastewater biodegradable organic fraction: Accuracy of the nitrate utilization rate test. Proc. of the Water Environ. Fed. 71 st Ann. Conf. \& Expo. October 3-7, Vol.1, Wastewater Treatment Research and Municipal Wastewater Treatment, Orlando, USA, 247-256.

WENTZEL MC, CLAYTON JA, LILLEY ID, EKAMA GA, LOEWENTHAL RE and MARAIS GvR (1991) Consolidation of Activated Sludge and Water Chemistry Research (Jan 1988 - Dec 1990). WRC Report 251/1/91.

WILSON AW, DO P and KELLER WE (1998) Implementation of the biological nutrient removal program at Calgary's Bonnybrook Wastewater Treatment Plant. Proc. $19^{\text {th }}$ Bienn. Conf. of the IAWQ. June 21-26, Vancouver, Canada.

WILSON AW and DOLD PL (1998) General methodology for applying process simulators to wastewater treatment plants. Proc. of the Water Environ. Fed. 71 ${ }^{\text {st }}$ Ann. Conf. \& Expo. October 3-7, Vol. 1, Wastewater Treatment Research and Municipal Wastewater Treatment, Orlando, USA, 575-585.

WRC (1984) Theory, Design and Operation of Nutrient Removal Activated Sludge Processes. WRC, South Africa.

XUS and HULTMANB (1996) Experiences in wastewater characterization and model calibration for the activated sludge process. Water Sci. Technol. 89-98. 


\section{APPENDIX A}

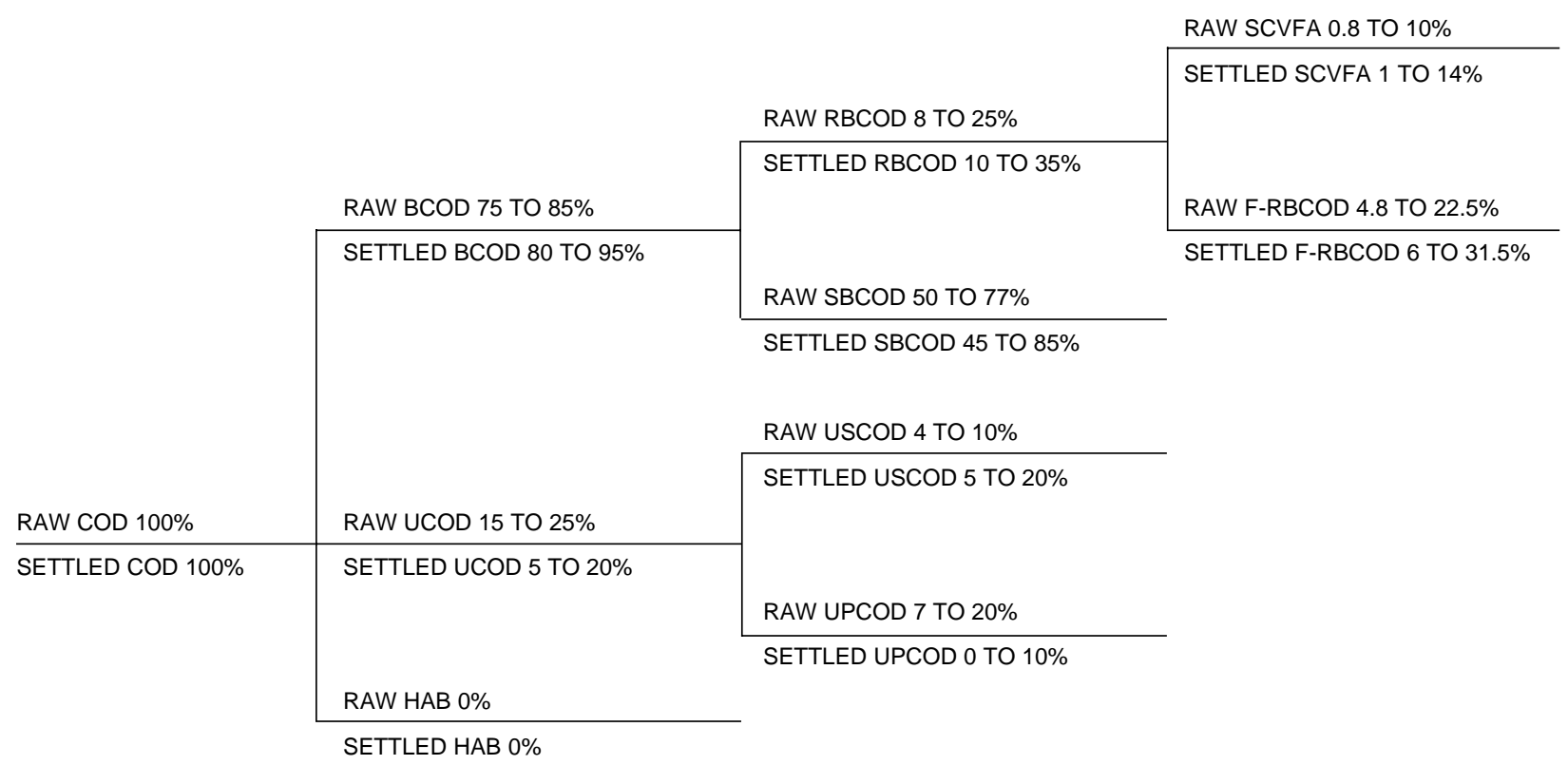

Figure 1

Schematic representation of key chemical oxygen demand fractions in a typical raw and settled sewage, as percentage limits of total chemical oxygen demand

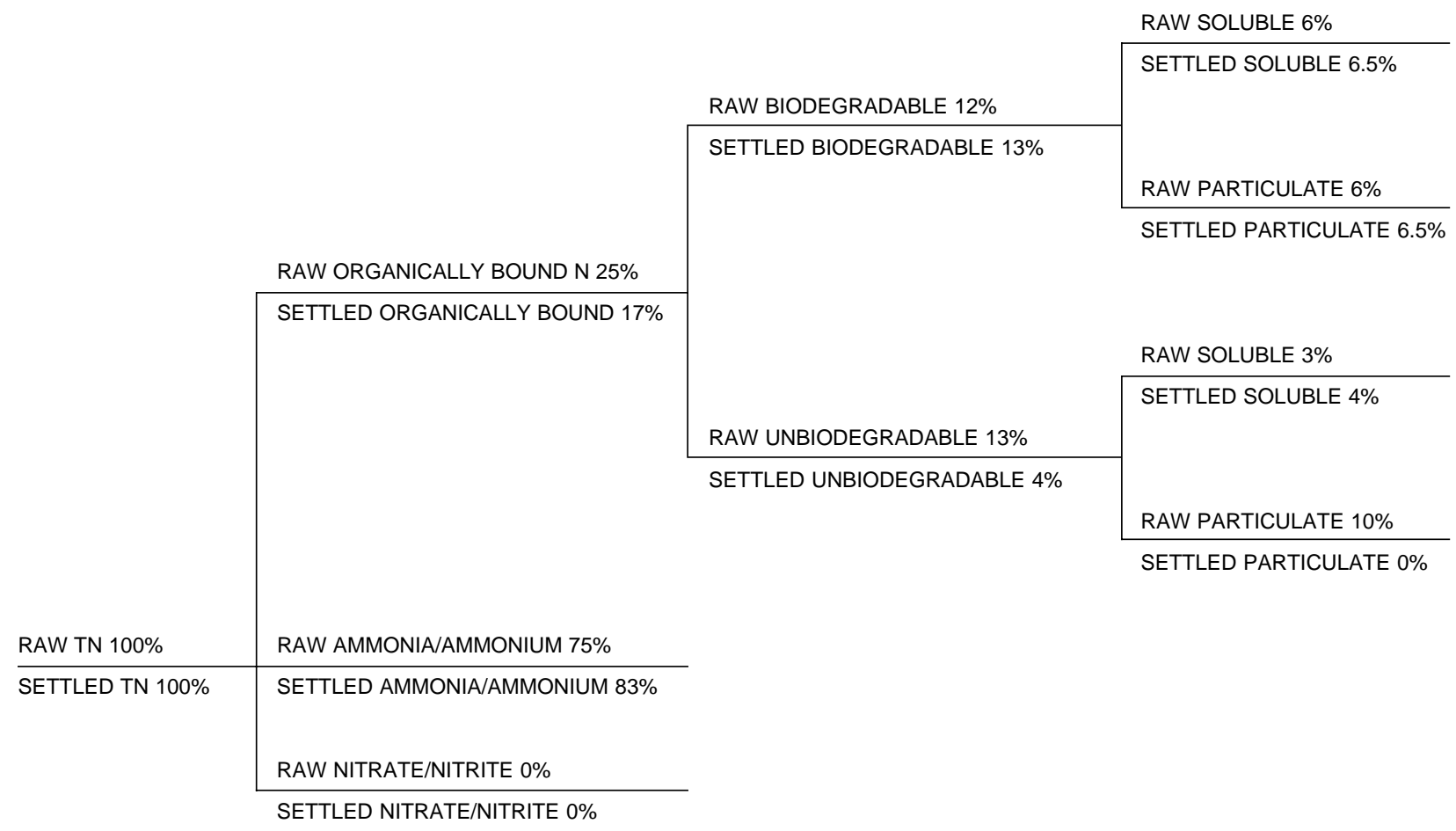

Figure 2

Schematic representation of key nitrogen fractions in a typical raw and settled sewage, as percentages of total nitrogen 